\title{
The influence of different concentrations of feed additive, based on shell rock and bentonite, on the growth, blood and meat parameters of the African black ostrich (Struthio camelus) in south-east Kazakhstan
}

\author{
Uldana Shameeva ${ }^{1}$, Przemysław Sobiech ${ }^{2 *}$, Gulmira Zhanabekova ${ }^{1}$, \\ Akylbek Zhumageldiev ${ }^{1}$, Altay Ussenbayev ${ }^{1}$, Damir Khusainov ${ }^{1}$, \\ Dominika Wysocka ${ }^{2}$, Anna Snarska ${ }^{2}$, and Marko Samardžija ${ }^{3}$ \\ ${ }^{\prime}$ Kazakh National Agrarian University, Almaty, Kazakhstan \\ ${ }^{2}$ Department and Clinic of Internal Diseases, Faculty of Veterinary Medicine, University of Warmia and \\ Mazury in Olsztyn, Olsztyn, Poland \\ ${ }^{3}$ Clinic for Reproduction and Obstetrics, Faculty of Veterinary Medicine, University of Zagreb, \\ Zagreb, Croatia
}

SHAMEEVA, U., P. SOBIECH, G. ZHANABEKOVA, A. ZHUMAGELDIEV, A. USSENBAYEV, D. KHUSAINOV, D. WYSOCKA, A. SNARSKA, M. SAMARDŽIJA: The influence of different concentrations of feed additive, based on shell rock and bentonite, on the growth, blood and meat parameters of the African black ostrich (Struthio camelus) in south-east Kazakhstan. Vet. arhiv 88, 413-425, 2018.

\section{ABSTRACT}

Forty-eight 3-month old African ostrich females were divided into four groups: control and 3 experimental comprising 12 animals each. All the animals were fed the adopted diet and the experimental groups additionally received a feed supplement based on shell rock and bentonite, at a rate of $5 \mathrm{~g} / \mathrm{kg}, 10 \mathrm{~g} / \mathrm{kg}$ and $15 \mathrm{~g} / \mathrm{kg}$, respectively, for 9 months. At the beginning and the end of the experiment blood samples were collected for hematological and biochemical analyses. At the end of the experiment, 3 ostriches from each group were slaughtered and the quality of their meat was examined. At 12 months of age the weight of the birds in the experimental groups was significantly higher $(\mathrm{P} \leq 0.05)$ in comparison to the control group, by $11 \mathrm{~kg}, 13.3 \mathrm{~kg}$ or $16.4 \mathrm{~kg}$, respectively. During the experiment, an increase in the number of red blood cells, leukocytes and hemoglobin was recorded, however all tested hematological parameters remained within the range of physiological values. The biochemical blood parameters in all groups of ostriches did not change significantly at the beginning and the end of experiment. However, the levels of total protein, glucose, $\mathrm{Ca}$ and $\mathrm{P}$ in the experimental groups

\footnotetext{
${ }^{*}$ Corresponding author:

Prof. Przemysław Sobiech, UWM, Dr Hab., Oczapowskiego 14 St, 10-597, Olsztyn, Poland, Phone: +48 8953232 94; E-mail: psobiech@uwm.edu.pl
} 


\section{U. Shameeva et al.: Influence of feed additive in the African black ostrich}

showed an upward trend in correlation with the dosage of the tested feed additive. Feed additive contributed to a change in the chemical composition and biological value of the meat. In comparison with the control group, an increase in ash, fat, protein and energy content, the level of mineral elements and vitamins in the meat of the experimental ostriches was noted, in a reliable dependence on the inclusion rate of the feed additive $(\mathrm{P} \leq 0.05)$. We concluded that the use of feed additive positively affects body mass and hematological blood parameters, as well as the nutritional and biological value of ostrich meat.

Key words: African ostrich; feed additive; chromatography; ostrich meat

\section{Introduction}

In recent years, in addition to the usual chicken, duck, goose and turkey meat, the Kazakh poultry industry has also been producing exotic products such as ostrich meat. Ostrich meat gained global popularity at the end of the last century, when people were striving for a more healthy diet and lifestyle (SHANAWANY and DINGLE 1999). This direction in meat production was also facilitated by the increased consumer mistrust of traditional types of meat produced on an industrial level with the use of chemical additives, and the emergence of animal diseases such as spongiform encephalopathy of livestock, etc.

The escalating demand for ostrich meat has contributed to the development of ostrich poultry farms and the rapid progress of ostrich farming worldwide. Kazakhstan has great potential for the development of this segment of poultry production, because the country has a favorable climate, abundant fodder base, accessible labor resources, and easily adaptable livestock and poultry farming infrastructure. At present, ostrich farms operate in Almaty, Kostanay and Mangistau districts, rearing about 5,000 ostriches.

Ostrich meat has a pleasant taste and aroma, with texture and flavor resembling veal or beef. It has a high protein content, accompanied by low caloric content. The amount of fat and cholesterol in ostrich meat is lower than in chicken and turkey meat (KULIKOV and SPIRIDINOV 2001). The economic efficiency and intensity of ostrich farming depend on a scientifically based system of breeding and feeding, which takes into account the characteristics of ostriches. For proper functioning and reproduction, a bird needs a full and varied diet, with physicochemical composition and the ratio of feed ingredients that satisfy the organism's needs for energy generation and the growth of new cells and tissues (BROWN and JONES 1996). Nutrient deficiency, which is prevalent in commercial ostrich farming, might be caused by improper feed formulation and its storage conditions. These shortcomings lead to a decrease in growth rate, deformation of the limb bones and the death of young birds (TULLIO, 1998).

A large number of feed additives, prepared on the basis of industrial fodder production, are used worldwide to increase productivity in ostrich breeding and to improve the quality of meat, eggs and other ostrich products (AGANGA and AGANGA 2003). Given the 


\section{U. Shameeva et al.: Influence of feed additive in the African black ostrich}

physiological characteristics of the digestion and the nutritional demands of the ostrich, it is considered relevant to use feed additives based on natural minerals (BOVERA and MONIELLO 2007).

However, in Kazakhstan, where this segment of the poultry industry is relatively new, the use of feed additives dedicated solely to ostriches is currently at the stage of research and initial introduction.

The aim of this study was to determine the effect of the proposed feed additive, based on shell rock and bentonite, on the growth indicators, blood and meat parameters of the African black ostrich.

\section{Materials and methods}

On the"Aikanat Kustary" farm 48 African black ostrich females, 3 month old were selected for the experiment. According to the principle of analogues, four groups of 12 individuals were created and separated into individual pens. The basic daily diet of each ostrich in every group included concentrated fodder at the rate of $10 \mathrm{~g} / \mathrm{kg}$ of body mass, $17 \mathrm{~g} / \mathrm{kg}$ of crushed corn and corn silage, $20 \mathrm{~g} / \mathrm{kg}$ of alfalfa hay, $13-20 \mathrm{~g} / \mathrm{kg}$ of main food (green parts of plants). In addition, the feed supplement containing shell rock (38.25\%), bentonite $(38.25 \%)$, bischofite $(4.5 \%)$, elemental sulfur $(4 \%)$, sodium selenite $(0.000004 \%)$, potassium iodide $(0.001 \%)$, iron sulfate $(0.01 \%)$, zinc sulfate $(0.001 \%)$, dry brewer's yeast $(2.5 \%)$, dry acidophilus milk (1.5\%), fish meal $(2.5 \%)$, meat and bone meal $(4 \%)$, flour from nettle $(4 \%)$, flour from licorice roots $(0.1 \%)$, and flour from plantain leaves $(0.1 \%)$, was introduced to the diet of the animals in the experimental groups. Birds from the first group were treated as the control group and did not receive any feed supplement. Birds from the second, third and fourth groups received $5 \mathrm{~g} / \mathrm{kg}$, $10 \mathrm{~g} / \mathrm{kg}$ and $15 \mathrm{~g} / \mathrm{kg}$ of feed supplement, respectively. Birds received water from semiautomatic drinkers, and a centralized water supply system was used. The experiment was carried out according to the fattening regime for ostriches and lasted for 9 months.

Examination of the physiological state of birds was performed sequentially once a week, beginning with the head and ending with the limbs. In the course of the examination changes in the behavior and appearance of the ostriches were recorded. Their temperature was measured using an electronic thermometer. Their respiratory rate was determined visually by observing chest movements. Before the experiment began and before slaughter the birds' body mass was estimated using an electronic EziWeigh2 scale, and total weight gain was calculated. All manipulation with the birds was performed in quiet and peaceful conditions, whereby to simplify procedures, the head of the ostrich was covered with a dark hood, with a hole for the beak.

Hematological analysis was performed at the beginning and end of the experiment. Blood was collected in the morning before feeding (on an empty stomach) from the 
jugular or ulnar vein into test tubes with a heparinized medium. The blood taken for analysis was examined in the IDK laboratory (Almaty) using an automatic Hitachi-902 analyzer (Roshe-Hitachi, Japan).

At the end of the experiment, three ostriches from each group were chosen for slaughter and transferred to a separate pen, where pre-slaughter preparation, with free access to water and without feeding, was carried out for 10-12 hours. Pre-slaughter, slaughter, and post-mortem examinations of the birds were executed in accordance with the rules of law in Kazakhstan.

The organoleptic properties of the meat were determined using the following parameters: the external condition of the carcass, the appearance and color of the muscles in the section, the consistency and smell of the meat, the condition of the tendons, fat, transparency and aroma of the broth according to GOST 31470-2012: "Poultry meat, bye-products and semi-finished products from poultry meat. Methods of sampling and organoleptic methods for determining freshness."

For biochemical analyses, 12 samples of meat of $200 \mathrm{~g}$ each, were taken from the femoral muscles of each carcass of the slaughtered birds. Analysis of each indicator of meat tissue was conducted with three-fold repetition.

Determination of the total chemical composition of the meat was executed in the following order: the moisture content by the drying method (GOST 9793-74 "Meat products, methods for determining moisture"), the amount of fat by Soxlet (GOST 23042-86 "Meat and meat products, methods for determining fat"), the percentage of proteins (GOST 25011-81 "Meat and meat products, methods for determining protein"). The energy value was determined from the calculation that $1 \mathrm{~g}$ of proteins gives 4.0, and $1 \mathrm{~g}$ of fat gives $9.0 \mathrm{kcal}$ of energy respectively. Vitamin composition was established by fluorometric (for vitamins of group B) and colorimetric (for vitamin PP) methods. The mineral composition was calculated by atomic absorption ( $\mathrm{Na}, \mathrm{Fe}, \mathrm{K}, \mathrm{Mg}$ and $\mathrm{Ca}$ ).

The data obtained were processed by the Student $t$-test for the reliability of the differences, using the Microsoft Excel 2007 software package. The differences were considered statistically significant at $\mathrm{P}<0.05$.

\section{Results}

The effect of feed additive on the body mass of the ostriches is presented in Table 1 . The experiment showed that the ostriches in the experimental groups gained weight more intensively than the birds in the control group. It should be noted that in the experimental groups the greatest increase in body mass was noted in birds in the fourth group: $16.60 \mathrm{~kg}$ more $(\mathrm{P} \leq 0.05)$ than in the control group. 
Table 2 shows the clinical status of the birds during the experiment. Animals from all four groups grew and developed intensively. Thus, during the experiment physiological parameters, such as body temperature, pulse rate and the number of respiratory movements, remained within the norm for each period of ostrich development. The birds manifested a healthy appearance and reacted adequately to external stimuli.

Table 1. The effects of feed additive on body mass gain (BMG) in the ostriches fed with different daily doses of supplement for 9 months

\begin{tabular}{|c|c|c|c|c|}
\hline \multirow{2}{*}{$\begin{array}{l}\text { Age of animals } \\
\text { (months) }\end{array}$} & \multicolumn{4}{|c|}{ Group of animals* } \\
\cline { 2 - 5 } & First (control) & Second $(5 \mathrm{~g} / \mathrm{kg})$ & Third $(10 \mathrm{~g} / \mathrm{kg})$ & Fourth $(15 \mathrm{~g} / \mathrm{kg})$ \\
\hline \multicolumn{5}{|c|}{ Mean BMG $(\mathrm{kg}) \pm \mathrm{SD}$} \\
\hline 3 & $27.92 \pm 0.43$ & $27.64 \pm 0.49$ & $27.85 \pm 0.51$ & $27.67 \pm 0.47$ \\
\hline 9 & $76.4 \pm 1.89$ & $82.5 \pm 2.87^{* *}$ & $84.6 \pm 3.10^{* *}$ & $87.5 \pm 2.62^{* *}$ \\
\hline 12 & $99.34 \pm 2.35$ & $110.36 \pm 5.56^{* *}$ & $112.62 \pm 3.41^{* *}$ & $115.74 \pm 4.29^{* *}$ \\
\hline
\end{tabular}

*Groups comprised 12 animals each. **Differences between values obtained for control and experimental groups were significant at $\mathrm{P} \leq 0.05$.

Table 2. Clinical status of the ostriches during the experiment

\begin{tabular}{|c|c|c|c|c|}
\hline \multirow{2}{*}{$\begin{array}{l}\text { Age of animals } \\
\text { (months) }\end{array}$} & \multicolumn{4}{|c|}{ Group of animals* } \\
\hline & First (control) & Second $(5 \mathrm{~g} / \mathrm{kg})$ & Third $(10 \mathrm{~g} / \mathrm{kg})$ & Fourth $(15 \mathrm{~g} / \mathrm{kg})$ \\
\hline \multicolumn{5}{|c|}{ Mean body temperature $\left({ }^{\circ} \mathrm{C}\right) \pm \mathrm{SD}$} \\
\hline \multirow{3}{*}{3} & $37.9 \pm 0.01$ & $37.73 \pm 1.2$ & $37.8 \pm 0.80$ & $38.2 \pm 0.07$ \\
\hline & $38.6 \pm 0.3$ & $38.5 \pm 0.05$ & $38.3 \pm 0,03$ & $38.1 \pm 1.02$ \\
\hline & $38.8 \pm 1.4$ & $38.7 \pm 0.1$ & $38.6 \pm 0,70$ & $38.8 \pm 0.5$ \\
\hline \multicolumn{5}{|c|}{ Mean the pulse rate $/ \min \pm \mathrm{SD}$} \\
\hline \multirow{3}{*}{9} & $97.5 \pm 3.1$ & $98.6 \pm 3.4$ & $98.9 \pm 2,02$ & $98.1 \pm 3.6$ \\
\hline & $52.4 \pm 1.2$ & $57.3 \pm 1.7$ & $58.8 \pm 1.9$ & $58.4 \pm 1.1$ \\
\hline & $30.3 \pm 1.09$ & $31.5 \pm 0.8$ & $30.8 \pm 1.4$ & $31.1 \pm 1.03$ \\
\hline \multicolumn{5}{|c|}{ Mean respiratory movements/ $\min \pm \mathrm{SD}$} \\
\hline \multirow{3}{*}{12} & $6.3 \pm 0.17$ & $6.8 \pm 0.2$ & $6.5 \pm 0.13$ & $6.3 \pm 0.24$ \\
\hline & $8.1 \pm 0.7$ & $8.6 \pm 0.5$ & $8.5 \pm 0.12$ & $8.3 \pm 0.03$ \\
\hline & $11.4 \pm 0.29$ & $11.8 \pm 0.17$ & $11.3 \pm 0.15$ & $11.42 \pm 0.25$ \\
\hline
\end{tabular}

*Groups comprised 12 animals each

The effects of this feed additive on the hematological parameters of the ostrich are presented in Table 3. In the course of the experiment, the quantitative composition of the blood elements in all groups of ostriches changed. It was established that the red 


\section{U. Shameeva et al.: Influence of feed additive in the African black ostrich}

blood cells, leukocytes and hemoglobin content in the birds' blood at the beginning of the experiment did not change significantly. During the experiment, an increase in the number of red blood cells, leukocytes and hemoglobin was recorded. However, all tested hematological parameters remained within physiological values.

Table 3. The effect of feed additive on the hematologic parameters of blood

\begin{tabular}{|c|c|c|c|c|}
\hline \multirow{2}{*}{$\begin{array}{l}\text { Age of animals } \\
\text { (months) }\end{array}$} & Group of animals* \\
\cline { 2 - 5 } & First (control) & Second $(5 \mathrm{~g} / \mathrm{kg})$ & Third $(10 \mathrm{~g} / \mathrm{kg})$ & Fourth $(15 \mathrm{~g} / \mathrm{kg})$ \\
\hline \multicolumn{5}{|c|}{ Mean hemoglobin $(10 \mathrm{~g} / \mathrm{L}) \pm \mathrm{SD}$} \\
\hline 3 & $9.8 \pm 1.38$ & $9.5 \pm 1.32$ & $9.6 \pm 1.29$ & $9.4 \pm 1.36$ \\
\hline 12 & $12.9 \pm 1.64$ & $13.7 \pm 1.58^{*}$ & $13.9 \pm 1.52^{* *}$ & $14.1 \pm 1.61^{* *}$ \\
\hline \multicolumn{6}{|c|}{ Mean erythrocytes (x10 $) \pm \mathrm{SD}$} \\
\hline 3 & $1.74 \pm 0.25$ & $1.71 \pm 0.19$ & $1.73 \pm 0.26$ & $1.70 \pm 0.22$ \\
\hline 12 & $2.22 \pm 0.72$ & $2.53 \pm 0.65^{* *}$ & $2.67 \pm 0.87^{* *}$ & $2.98 \pm 0.56^{* *}$ \\
\hline \multicolumn{7}{|c|}{ Mean leukocytes (x10 $) \pm \mathrm{SD}$} \\
\hline 3 & $4.3 \pm 0.95$ & $4.1 \pm 0.89$ & $4.14 \pm 1.02$ & $4.01 \pm 0.92$ \\
\hline 12 & $5.1 \pm 0.85$ & $5.42 \pm 0.99^{* *}$ & $5.25 \pm 1.08$ & $5.51 \pm 1.12^{* *}$ \\
\hline
\end{tabular}

*Groups comprised 12 animals each. **Differences between values obtained for control and experimental groups were significant at $\mathrm{P} \leq 0.05$.

The effect of the feed additive on the biochemical blood parameters is presented in Table 4. The biochemical parameters of the blood in all groups of ostriches did not change significantly between the beginning and the end of the experiment. However, the levels of total protein, glucose, $\mathrm{Ca}$ and $\mathrm{P}$ showed an increasing trend in the experimental groups, which correlated with the dosage of feed additive tested.

Table 4. Effect of feed aditive on biochemical blood parameters

\begin{tabular}{|c|c|c|c|c|}
\hline \multirow{2}{*}{$\begin{array}{l}\text { Age of animals } \\
\text { (months) }\end{array}$} & Group of animals* \\
\cline { 2 - 5 } & First (control) & Second $(5 \mathrm{~g} / \mathrm{kg})$ & Third $(10 \mathrm{~g} / \mathrm{kg})$ & Fourth $(15 \mathrm{~g} / \mathrm{kg})$ \\
\hline \multicolumn{5}{|c|}{ Mean total protein $(\mathrm{g} / 100 \mathrm{~mL}) \pm \mathrm{SD}$} \\
\hline 3 & $3.79 \pm 0.87$ & $3.82 \pm 0.92$ & $3.84 \pm 0.95$ & $3.89 \pm 1.24$ \\
\hline 12 & $4.12 \pm 1.45$ & $4.27 \pm 1.80$ & $4.42 \pm 1.92$ & $4.67 \pm 2.2$ \\
\hline \multicolumn{5}{|c|}{ Mean total bilirubin, (mg/100 mL) $\pm \mathrm{SD}$} \\
\hline 3 & $0.13 \pm 0.07$ & $0.13 \pm 0.09$ & $0.13 \pm 0.09$ & $0.13 \pm 0.07$ \\
\hline 12 & $0.14 \pm 0.04$ & $0.14 \pm 0.02$ & $0.14 \pm 0.01$ & $0.14 \pm 0.05$ \\
\hline
\end{tabular}

*Groups comprised 12 animals each 
U. Shameeva et al.: Influence of feed additive in the African black ostrich

Table 4. Effect of feed aditive on biochemical blood parameters (continued)

\begin{tabular}{|c|c|c|c|c|}
\hline \multirow{2}{*}{$\begin{array}{l}\text { Age of animals } \\
\text { (months) }\end{array}$} & \multicolumn{4}{|c|}{ Group of animals* } \\
\hline & First (control) & Second $(5 \mathrm{~g} / \mathrm{kg})$ & Third $(10 \mathrm{~g} / \mathrm{kg})$ & Fourth $(15 \mathrm{~g} / \mathrm{kg})$ \\
\hline \multicolumn{5}{|c|}{ Mean glucose $(\mathrm{mg} / 100 \mathrm{~mL}) \pm \mathrm{SD}$} \\
\hline 3 & $9.3 \pm 3.01$ & $9.1 \pm 4.21$ & $9.32 \pm 2.65$ & $9.23 \pm 3.02$ \\
\hline 12 & $10.89 \pm 3.6$ & $11.25 \pm 2.8$ & $11.67 \pm 2.4$ & $11.89 \pm 1.7$ \\
\hline \multicolumn{5}{|c|}{ Mean cholesterol $(\mathrm{mg} / 100 \mathrm{~mL}) \pm \mathrm{SD}$} \\
\hline 3 & $1.33 \pm 0.21$ & $1.35 \pm 0.15$ & $1.33 \pm 0.19$ & $1.31 \pm 0.17$ \\
\hline 12 & $1.68 \pm 0.11$ & $1.63 \pm 0.19$ & $1.64 \pm 0.22$ & $1.62 \pm 0.15$ \\
\hline \multicolumn{5}{|c|}{ Mean uric acid $(\mathrm{g} / 100 \mathrm{~mL}) \pm \mathrm{SD}$} \\
\hline 3 & $0.25 \pm 0.06$ & $0.23 \pm 0.02$ & $0.24 \pm 0.08$ & $0.25 \pm 0.03$ \\
\hline 12 & $0.32 \pm 0.11$ & $0.30 \pm 0.17$ & $0.29 \pm 0.14$ & $0.29 \pm 0.09$ \\
\hline \multicolumn{5}{|c|}{ Mean alkaline phosphatase $(\mathrm{U} / \mathrm{L}) \pm \mathrm{SD}$} \\
\hline 3 & $31.1 \pm 3.1$ & $30.9 \pm 4.25$ & $30.2 \pm 2.7$ & $30.8 \pm 2.9$ \\
\hline 12 & $21.4 \pm 2.97$ & $21.1 \pm 3.21$ & $20.9 \pm 3.9$ & $20.8 \pm 4.05$ \\
\hline \multicolumn{5}{|c|}{ Mean ALT $(\mathrm{U} / \mathrm{L}) \pm \mathrm{SD}$} \\
\hline 3 & $16.9 \pm 3.71$ & $16.7 \pm 4.2$ & $16.5 \pm 3.3$ & $16.8 \pm 2.4$ \\
\hline 12 & $20.6 \pm 4.36$ & $20.57 \pm 3.1$ & $20.52 \pm 3.24$ & $20.56 \pm 3.6$ \\
\hline \multicolumn{5}{|c|}{ Mean ASP $(U / L) \pm$ SD } \\
\hline 3 & $151.7 \pm 35.2$ & $152.7 \pm 28.5$ & $152.3 \pm 23.5$ & $151.6 \pm 21.9$ \\
\hline 12 & $194.5 \pm 39.4$ & $190.7 \pm 32.3$ & $190.5 \pm 27.1$ & $190.3 \pm 23.5$ \\
\hline \multicolumn{5}{|c|}{ Mean Ca $(\mathrm{mg} / 100 \mathrm{~mL}) \pm \mathrm{SD}$} \\
\hline 3 & $1.9 \pm 0.63$ & $1.89 \pm 0.52$ & $1.92 \pm 0.51$ & $1.91 \pm 0.54$ \\
\hline 12 & $3.5 \pm 0.96$ & $3.6 \pm 1.07$ & $3.7 \pm 0.81$ & $3.9 \pm 0.99$ \\
\hline \multicolumn{5}{|c|}{ Mean P $(\mathrm{mg} / 100 \mathrm{~mL}) \pm \mathrm{SD}$} \\
\hline 3 & $1.05 \pm 0.40$ & $1.07 \pm 0.52$ & $1.06 \pm 0.36$ & $1.05 \pm 0.37$ \\
\hline 12 & $3.71 \pm 0.82$ & $3.75 \pm 0.94$ & $3.79 \pm 1.03$ & $3.88 \pm 0.96$ \\
\hline \multicolumn{5}{|c|}{ Mean creatinine $(\mathrm{U} / \mathrm{L}) \pm \mathrm{SD}$} \\
\hline 3 & $0.62 \pm 0.34$ & $0.62 \pm 0.22$ & $0.62 \pm 0.38$ & $0.62 \pm 0.25$ \\
\hline 12 & $0.64 \pm 0.22$ & $0.65 \pm 0.41$ & $0.65 \pm 0.29$ & $0.65 \pm 0.36$ \\
\hline
\end{tabular}

*Groups comprised 12 animals each 


\section{U. Shameeva et al.: Influence of feed additive in the African black ostrich}

Data regarding the chemical composition (vitamins and minerals) of ostrich meat are presented in Tables 5, 6, 7, respectively. The feed additive proposed in this study significantly affected the ash, fat, protein content and energy value of the ostrich meat, which is shown in Table 5. We also observed a significant increase in vitamins $\mathrm{B}_{1}, \mathrm{~B}_{2}, \mathrm{PP}$ in the experimental animals in comparison with the control group, which is presented in Table 6.

Regarding minerals, the meat of the animals from the experimental groups, depending on the amount of feed additive given, showed a relative increase in $\mathrm{Fe}, \mathrm{Mg}, \mathrm{Mn}, \mathrm{K}$ and $\mathrm{Na}$ content in comparison with the control group, which is shown in Table 7.

Table 5. Chemical composition of ostrich meat (Mean \pm SD)

\begin{tabular}{|l|c|c|c|c|}
\hline \multirow{2}{*}{ Parameter } & \multicolumn{4}{|c|}{ Group of animals* } \\
\cline { 2 - 5 } & First (control) & Second $(5 \mathrm{~g} / \mathrm{kg})$ & Third $(10 \mathrm{~g} / \mathrm{kg})$ & Fourth $(15 \mathrm{~g} / \mathrm{kg})$ \\
\hline Moisture (\%) & $66.44 \pm 12.1^{*}$ & $63.79 \pm 9.3$ & $62.4 \pm 10.12$ & $61.9 \pm 8.07$ \\
\hline Ash (\%) & $0.85 \pm 0.13$ & $0.89 \pm 0.09$ & $0.91 \pm 0.12$ & $0.94 \pm 0.18^{*}$ \\
\hline Fat (\%) & $3.94 \pm 0.81$ & $4.19 \pm 1.01^{*}$ & $4.37 \pm 1.06^{*}$ & $4.7 \pm 0.92^{*}$ \\
\hline Protein (\%) & $28.77 \pm 3.01$ & $30.4 \pm 2.82^{*}$ & $30.5 \pm 3.5^{*}$ & $30.9 \pm 3.41^{*}$ \\
\hline $\begin{array}{l}\text { Energy value per } \\
100 \text { g (kcal) }\end{array}$ & $151 \pm 32.9$ & $159 \pm 29.4$ & $161 \pm 27.09^{*}$ & $163 \pm 29.7^{*}$ \\
\hline
\end{tabular}

*Groups comprised 12 animals each. *Differences between values obtained for control and experimental groups were significant at $\mathrm{P} \leq 0.05$.

Table 6. Vitamin composition of ostrich meat $(\mathrm{mg} / 100 \mathrm{~g})($ Mean \pm SD)

\begin{tabular}{|c|c|c|c|c|}
\hline \multirow{2}{*}{ Vitamin } & \multicolumn{4}{|c|}{ Group of animals* } \\
\cline { 2 - 5 } & First (control) & Second $(5 \mathrm{~g} / \mathrm{kg})$ & Third $(10 \mathrm{~g} / \mathrm{kg})$ & Fourth $(15 \mathrm{~g} / \mathrm{kg})$ \\
\hline $\mathrm{A}$ & $0.013 \pm 0.004$ & $0.015 \pm 0.002$ & $0.016 \pm 0.004$ & $0.019 \pm 0.001$ \\
\hline $\mathrm{E}$ & $0.25 \pm 0.04$ & $0.27 \pm 0.03$ & $0.30 \pm 0.05$ & $0.31 \pm 0.09$ \\
\hline $\mathrm{B}_{1}$ & $0.22 \pm 0.03$ & $0.24 \pm 0.02$ & $0.25 \pm 0.05$ & $0.29 \pm 0.07^{*}$ \\
\hline $\mathrm{B}_{2}$ & $0.31 \pm 0.04$ & $0.35 \pm 0,06$ & $0.39 \pm 0.03$ & $0.45 \pm 0.09^{*}$ \\
\hline PP & $7.23 \pm 1.02$ & $7.4 \pm 1.45^{*}$ & $7.7 \pm 1.63^{*}$ & $7.9 \pm 2.01^{*}$ \\
\hline
\end{tabular}

*Differences between values obtained for control and experimental groups were significant at $\mathrm{P} \leq 0.05$ 
U. Shameeva et al.: Influence of feed additive in the African black ostrich

Table 7. Mineral content in ostrich meat $(\mathrm{mg} / 100 \mathrm{~g})(\mathrm{Mean} \pm \mathrm{SD})$

\begin{tabular}{|l|c|c|c|c|}
\hline \multirow{2}{*}{ Mineral } & \multicolumn{4}{|c|}{ Group of animals* } \\
\cline { 2 - 5 } & First (control) & Second $(5 \mathrm{~g} / \mathrm{kg})$ & Third $(10 \mathrm{~g} / \mathrm{kg})$ & Fourth $(15 \mathrm{~g} / \mathrm{kg})$ \\
\hline Iron $(\mathrm{Fe})$ & $4.97 \pm 1.53$ & $5.49 \pm 2.02^{*}$ & $5.64 \pm 1.86^{*}$ & $5.85 \pm 2.15^{*}$ \\
\hline Potassium $(\mathrm{K})$ & $412 \pm 31.3$ & $425 \pm 42.05$ & $439 \pm 31.2^{*}$ & $441 \pm 53.4^{*}$ \\
\hline Magnesium $(\mathrm{Mg})$ & $27 \pm 4.4$ & $29 \pm 2.8$ & $31 \pm 5.1^{*}$ & $32.5 \pm 3.8^{*}$ \\
\hline Sodium $(\mathrm{Na})$ & $83 \pm 8.05$ & $85 \pm 6.1$ & $86 \pm 5.24$ & $88 \pm 7.5$ \\
\hline Calcium $(\mathrm{Ca})$ & $8 \pm 2.1$ & $10 \pm 1.8$ & $11.6 \pm 1.9$ & $12.8 \pm 3.2^{*}$ \\
\hline Phosphorus $(\mathrm{P})$ & $279 \pm 42.17$ & $294 \pm 49.3$ & $294 \pm 52.9$ & $296 \pm 54.2^{*}$ \\
\hline Manganese $(\mathrm{Mn})$ & $0.025 \pm 0.002$ & $0.027 \pm 0.003$ & $0.029 \pm 0.001$ & $0.031 \pm 0.009$ \\
\hline
\end{tabular}

*Groups comprised 12 animals each. *Differences between values obtained for control and experimental groups were significant at $\mathrm{P} \leq 0.05$.

\section{Discussion}

Successful ostrich rearing requires high standards of nutrition. Ostrich meat producers should be knowledgeable about how each ingredient of the ostriches' diet provides essential nutrients for the birds' growth and development. Dried yeast supplementation improves the nutritive quality of the basal poultry diet. (ONIFADE 1997). Considering the fact that our experimental groups had a higher weight gain than the control group, it may be concluded that dried yeast contributed to better nutrient assimilation and, in consequence, a higher growth rate. Another ingredient that may contribute to a higher growth rate is bentonite. It is known that it exhibits a tonic effect on the gastric mucosa and eliminates mycotoxicity (TOMASZEWSKA et al. 2016). Many studies addressing poultry feeding requirements have shown that probiotics can prevent diseases associated with administration of pathogenic organisms, reduce the number of pathogenic organisms recovered from test birds, and reduce shedding of pathogenic organisms (SMITH 2014). The results of our study correspond with this since the addition of dry acidophilus milk contributed to maintaining the birds' good condition during the experiment. The ostrich requires its own unique dietary mineral and vitamin supplements. Diets deficient in calcium or with a low calcium to phosphorus ratio, are thought to cause long bone deviation in ratites (COOPER and HORBAŃCZUK 2004). Fish meal and meat, and bone meal might be used as a source of calcium and phosphorus in the ostrich diet to prevent any symptoms of deficiencies (ULLREY and ALLEN 1996). Our results reflect this statement and indicate fish and bone meal as adequate sources of minerals for ostriches.

According to our results, the use of the feed additive in the ostrich diet improved the weight gain of birds at the age of slaughter. Similar results were observed when adding a biologically active feed additive of zeolite origin to the basic diet of ostriches, which had 
a positive effect on both the average body mass of the ostriches and their average daily weight gain.

It is known that the blood profile determines the physiological state of the bird's body (SPINU et al., 1999). The morphological and biochemical parameters of blood are influenced by many factors, such as genetics, age, sex, nutrition, physiological status, location, season, blood sampling method, stress and pathological conditions (BOVERA and MONIELLO 2007). Our study corresponded with this statement, and showed significant changes in some hematological parameters when the feed additive was included in the ostrich diet. The data obtained indicate that the use of the proposed feed additive for ostrich production has a positive effect on the concentration of hemoglobin and the number of erythrocytes. The quantitative values of total bilirubin, cholesterol, uric acid, alkaline phosphatase, alanine amine transferase (ALT), aspartate aminotransferase (ASP), creatinine did not undergo any significant changes in any ostrich group.

At the same time, it should be noted that in the experimental ostriches we observed changes in the mineral composition of the blood. In particular, in comparison with the control group, at the age of 12 months, in the second, third and fourth groups $(\mathrm{P} \leq 0.05)$, an increase was observed in Ca content of $0.1,0.2$ and $0.4 \mathrm{mg} / 100 \mathrm{~mL}$ and $\mathrm{P}-$ of $0.04 ; 0.08$ and $0.17 \mathrm{mg} / 100 \mathrm{~mL}$, respectively (Table 4). In general, the age-related dynamics of the quantitative change in the biochemical parameters of the blood corresponded to the data described in literature (SOLTAN et al., 2014).

It is known that the nutritional value of different parts of the carcass of a bird is not uniform. The thoracic and femoral parts, which contain the major proportion of the large pectoral and leg muscles and fewer bones, are most valued (CILLIERS et al., 1998). When examining the meat from the femoral part of ostrich carcasses grown under experimental conditions, it was found that the feed additive affected the moisture, ash, fat, protein and the energy value of meat (Table 5). Generally, in all the groups, the chemical composition of the meat corresponded to the properties of ostrich meat described in literature (HORBANCZUK et al., 1998, COOPER, 1999), with the fat level lower than in lamb, beef and chicken. The use of feed additive in our experiment led to a decrease in moisture content in the meat and an increase in ash, fat, protein and energy content, which indicates an increase in the nutritional value of the ostrich meat.

It is known that vitamins are essential for the proper functioning of animal organisms. The results of this experiment showed that the feed additive based on shell rock and bentonite also influenced the vitamin composition of the ostrich meat. In particular, the level of fat-soluble vitamins increased in all experimental groups in comparison to the control group of ostriches, and showed a reliable dependence on the amount of feed additive introduced to the diet (Table 6). It should be noted that the results obtained on the content of vitamins in ostrich meat correspond to the literature data, which is limited 
in general. At the same time, the total level of group B vitamins and vitamin E in the ostriches was equivalent to that in beef and higher than in chicken meat.

Meat is considered an important source of minerals, especially iron and zinc, and this largely determines the nutritional and biological value of the product (ŠIMPRAGA et al., 2004). It has been established that raw ostrich meat contains the highest content of Fe of all available meats. The content of mineral elements in the meat of the ostrich control group was within the values indicated by different researchers (ANDREWS et al., 2000). In addition, the feed supplement studied, contributed to a change in the mineral composition of the ostrich meat by significantly increasing the quantities of most of the minerals (Table 7).

\section{Conclusions}

As a result of this experiment, it was established that when using the feed additive based on shell rock and bentonite, the clinical status of the ostriches remains within the physiological values. In a correlation dependent on the amount of the supplement, the content of hemoglobin, erythrocytes, total protein, glucose, $\mathrm{Ca}$ and $\mathrm{P}$ in the blood, and the weight of the ostriches increased. The use of feed additive led to a decrease in moisture content, as well as an increase in the amount of ash, fat, protein and energy value, as well as vitamins (A, E, B, $\mathrm{B}_{2}$ and PP), minerals (Fe, K, Mg, Na, Ca, P, Mn) in the ostrich meat. Thus, the use of the developed feed additive increased the energy value, and improved the nutritional, biological and consumer value of the meat of the black African ostrich.

\section{References}

AGANGA, A. A., A. O. AGANGA (2003): Ostrich feeding and nutrition, Pakistan J. Nutrit. 2, 60-67.

DOI: $10.3923 /$ pjn.2003.60.67

ANDREWS, L., J. GILLESPIE, A. SCHUPP, G. TAYLOR (2000): Ratite meat sensory scores compared with beef. J. Food Qualit. 23, 351-359.

DOI: $10.1111 / j .1745-4557.2000 . t b 00220 . x$

BOVERA, F., N. MONIELLO (2007): Effect of diet on the metabolic profile of ostriches (Struthio camelus var. domesticus). Trop. Anim. Health Prod. 39, 265-270.

DOI 10.1007/s11250-007-9008-2

BROWN, C. R., G. E. JONES (1996): Some blood chemical, electrolyte and mineral values from young ostriches. J. South African Vet. Assoc. 67, 111-114.

CILLIERS, S. C, J. P. HAYES, A. CHWALIBOG, J. SALES, J. J. DuPREEZ (1998): Determination of energy, protein and amino acid requirements for maintenance and growth in ostriches. Anim. Feed Sci. Technol. 72, 283-293.

DOI: 10.1016/S0377-8401(97)00188-0 


\section{U. Shameeva et al.: Influence of feed additive in the African black ostrich}

COOPER, R. G. (1999): Ostrich meat, an important product of the ostrich industry: a Southern African perspective. World Poultry Sci. J. 55, 389-402.

DOI: 10.1079/WPS19990027

COOPER, R. G., J. O. HORBAŃCZUK (2004): Ostrich nutrition: a review from a Zimbabwean perspective Revue Scientifique et Technique (International Office of Epizootics) 23, 10331042.

DOI: $10.20506 /$ rst.23.3.1541

HORBANCZUK, J., J. SALES, T. CELEDA, A. KONECKA (1998): Cholesterol content and fatty acid composition of ostrich meat as influenced by subspecies. Meat Sci. 50, 385-388.

DOI: 10.1016/S0309-1740(98)00028-X

KULIKOV, L., A. SPIRIDONOV (2001): Ostrich of Italy. Poultry Farming 3, 52-53.

ONIFADE, A. A. (1997): Growth performance, carcass characteristics, organs measurement and haematology of broiler chickens fed a high fibre diet supplemented with antibiotics or dried yeast. Mol. Nutr. Food Res. 41, 370-374.

DOI:10.1002/food.19970410612

SHANAWANY, M. M., J. DINGLE (1999): Ostrich production systems. FAO Animal Production and Health Paper. Rome, p. 256.

ŠIMPRAGA, M., J. RAUKAR, I. L. NOVAK (2004): Calcium, phosphorus and magnesium levels and alkaline phosphatase activity in the blood of one-day old ostriches. Vet. arhiv 74, 177-188.

SMITH, J. M. (2014): A review of avian probiotics. J. Avian Med. Surg. 28, 87-94.

DOI: http://dx.doi.org/10.1647/2012-031

SOLTAN, M. E., A. A. ENAB, E. M. ABOU-ELEWAAND, S. A. FARRAG (2014): Effect of age and sex on some blood haematological and biochemical parameters of African black neck ostrich in Egypt. Proceedings of $7^{\text {th }}$ International Poultry Conference, 17 November, Egypt.

SPINU, M., O. SPINU, A. DEGEN (1999): Haematological and immunological variables in a domesticated and wild subspecies of ostrich (Struthio camelus). Br. Poult. Sci. 40, 613-618.

DOI: $10.1080 / 00071669986981$

TOMASZEWSKA, E., MUSZYŃSKI S., DOBROWOLSKI P., KOSTRO K., TASZKUN I., ŻMUDA A., BLICHARSKI T., KĘDZIA P. (2016): Bentonite diminishes DON-induced changes in bone development in mink dams. J. Vet. Res. 60, 349-355.

DOI: 10.1515 /jvetres-2016-0033

TULLIO, D. (1998): Lo struzzo, malato molto esigente. Revta Avicoltura 12, 23-26.

ULLREY, D. E., M. E. ALLEN (1996): Nutrition and feeding of ostriches. Anim. Feed Sci. Tech. $59,27-36$.

DOI: $10.1016 / 0377-8401(95) 00884-5$

Received: 30 June 2017

Accepted: 19 January 2018 
SHAMEEVA, U., P. SOBIECH, G. ZHANABEKOVA, A. ZHUMAGELDIEV, A. USSENBAYEV, D. KHUSAINOV, D. WYSOCKA, A. SNARSKA, M. SAMARDŽIJA: Utjecaj različitih koncentracija mješavine ljuske stijene i bentonita u hrani na rast, pokazatelje u krvi i mesu u afričkog crnog noja (Struthio camelus) iz jugoistočnog Kazahstana. Vet. arhiv 88, 413-425, 2018.

\section{SAŽETAK}

Četrdeset i osam crnih afričkih nojeva, ženki u dobi od tri mjeseca podijeljeno je u četiri skupine. U kontrolnoj i tri pokusne skupine bilo je po 12 životinja. Kontrolna (ili prva) skupina hranjena je prilagođenim obrokom, dok su pokusne skupine, druga, treća i četvrta, dodatno primale dodatak hrani, mješavinu ljuski stijena i bentonita u dozama od $5 \mathrm{~g} / \mathrm{kg}, 10 \mathrm{~g} / \mathrm{kg}$ ili $15 \mathrm{~g} / \mathrm{kg}$ tijekom 9 mjeseci. Na početku i na kraju pokusa uzimani su uzorci krvi za hematološke i biokemijske analize. Na kraju pokusa po 3 noja iz svake skupine je žrtvovano te je pretražena kakvoća njihova mesa. U dobi od 12 mjeseci u svim je skupinama utvrđeno značajno povećanje tjelesne mase: tjelesna masa ptica u pokusnim skupinama bila je značajno viša $(P \leq 0,05)$, i to za $11 \mathrm{~kg}$ u drugoj skupini, za 13,3 kg u trećoj skupini i za 16,4 kg u četvrtoj skupini, u usporedbi s kontrolnom skupinom. Tijekom pokusa opažen je porast brojnosti eritrocita, leukocita te koncentracije hemoglobina, ali su ti, kao i ostali testirani hematološki pokazatelji, bili unutar fizioloških vrijednosti. Biokemijski krvni pokazatelji u svim skupinama nojeva nisu se značajno mijenjali na početku ni na kraju pokusa. No, razine ukupnih proteina, glukoze, Ca i P, pokazivale su rastući trend u svim pokusnim skupinama u korelaciji s dozom testiranog dodatka hrani. Dodatak hrani utjecao je na promjene u kemijskom sastavu i biološkoj vrijednosti mesa. U usporedbi s kontrolnom skupinom, zabilježen je porast u sadržaju pepela, masti, proteina i energije te u razini minerala, vitamina i nekih aminokiselina u mesu pokusnih nojeva, u postojanoj ovisnosti o udjelu dodatka hrani $(\mathrm{P} \leq 0,05)$. Zaključili smo da je uporaba dodatka hrani povoljno utjecala na rast, hematološke pokazatelje krvi, kao i na nutritivnu i biološku vrijednost mesa nojeva.

Ključne riječi: afrički noj; dodatak hrani; kromatografija; meso noja 
